\title{
Cropping Pattern, Intensity and Diversity in Dhaka Region
}

\author{
N Parvin ${ }^{1 *}$, A Khatun ${ }^{1}$, M K Quais ${ }^{1}$ and M Nasim ${ }^{1}$
}

\begin{abstract}
Sustainable crop production in Bangladesh through improvement of cropping intensity and crop diversity in rice based cropping system is regarded as increasingly important in national issues. Planning of agricultural development largely depends on the authentic, reliable and comprehensive statistics of the existing cropping patterns, cropping intensity and crop diversity of a particular area, which will provide guideline to our policy makers, researchers, extensionists and development workers. The study was conducted over all 46 upazilas of Dhaka agricultural region in 2015 using pretested semi-structured questionnaire with a view to document the existing cropping patterns, cropping intensity and crop diversity in the region. From the present study, it was observed that about $48.27 \%$ net cropped area (NCA) is covered by exclusive rice cropping systems whereas deep water rice occupied about $16.57 \%$ of the regional NCA. The most dominant cropping pattern Boro-Fallow-T. Aman alone occupied about $22.59 \%$ of net cropped area (NCA) with its distribution over 32 upazilas out of 46 . The second largest area was covered by single Boro cropping pattern, which was spread over 44 upazilas. Total number of cropping patterns was observed 164 . The highest number of cropping pattern was identified 35 in Tangail sadar and Dhamrai upazila of Dhaka district and the lowest was seven in Bandar of Narayanganj and Palash of Narsingdi district. The lowest crop diversity index (CDI) was reported as 0.70 in Dhamrai followed by 0.72 in Monohardi of Narsingdi. The highest value of CDI was observed as 0.97 in Tangail sadar followed by 0.95 in Dhamrai of Dhaka and Bhuanpur of Tangail. The range of cropping intensity value was recorded $124-239 \%$. The maximum CDI was observed in Saturia upazila of Manikganj district and minimum in Sreenagar upazila of Munsiganj district. The CDI value for Dhaka region was calculated 0.94 and the average cropping intensity at regional level was $191 \%$.
\end{abstract}

Key words: Crop diversity index, land use, cropping intensity and deepwater ecosystem

\section{INTRODUCTION}

Agriculture is the science and practice of producing crops; and cropping pattern expresses the shares of various crops in the farmers' total cultivated area in an agricultural year. Cropping pattern is an important indicator of a farmer's decision making ability and also influences the consumption pattern as well as health and nutritional status of the people. Cropping pattern vary from region to region, country to country and culture to culture. Cropping systems of a region are decided by and large, by a number of soil and climatic parameters which determine overall agro-ecological setting for nourishment and appropriateness of a crop or set of crops for cultivation.
Bangladesh agriculture involves food production for over 162 million people from merely 8.75 million hectares of agricultural land (Salam et al., 2014) and it is shrinking day by day. The overall land area increased in the recent past is due to reclamation of char lands .The annual loss of agricultural land is about $0.73 \%$ per annum due to construction of houses, roads and industrial infrastructure (BBS, 2014). Sustainable crop production in Bangladesh through improvement of cropping intensity in rice based cropping system is regarded as increasingly important in national issues such as food security, poverty alleviation and creation of job opportunity. The main challenge of the new millennium is to increase $50 \%$ yield per unit land area through manipulating the

${ }^{1}$ Rice Farming Systems Division, BRRI, Gazipur; *Corresponding author's E-mail: nargisrfs@gmail.com 
limited land resource. In order to produce more food within a limited area, the most important options are i) to increase the cropping intensity by producing three or more crops over the same piece of land in a year and ii) to increase the production efficiency of the individual crop by using optimum management practices (Salam et al., 2014).

To meet the challenges of a globalizing market in agriculture as well as the growing and changing needs of the population, many countries in South East Asia have undertaken crop diversification to enhance productivity and cultivate high value crop with positive outcome. Diversification is taking place either through area augmentation or by crop substitution. If carried out appropriately, diversification can be used as a tool to augment farm income, generate employment, alleviate poverty and conserve precious soil and water resources (Pingali and Rosegrant, 1995; Chand, 1996). It can be said that present cropping pattern and crop diversification is a contemporary issue in the field of agriculture, especially in the context of Bangladesh. Therefore, it claims a comprehensive study for the betterment of the agriculture of the country. From the literature, it is found that there are a number of studies were carried out in different countries regarding this issue. However, a very few studies on this aspect was carried out in Bangladesh. In this study, the cropping pattern survey was carried out in Dhaka region to search the better opportunities for improvement of cropping intensity in this region through the cropping pattern analysis. In this backdrop, the present study is an attempt to analyze to the present scenario of cropping pattern and diversification of Dhaka region in Bangladesh. The present study was designed with the following specific objectives to:

- Understand the existing cropping pattern scenario in Dhaka region

- Visualize the existing land use pattern at upazila and regional level

- Determine the crop diversity and cropping intensity at local and regional level.

\section{METHODOLOGY}

Forty-six upazilas of Dhaka, Gazipur, Narsingdi, Manikganj, Munsiganj, Narayanganj and Tangail districts under Dhaka agricultural region were the locale of this study. Data were collected using double stage procedure. At initial stage, data were collected through pretested semi-structured questionnaire from 46 pre-assigned Sub-Assistant Agriculture Officers (SAAO) of each upazila during July 2015 at upazila level. SAAOs were purposively selected by Agriculture Extension Officers (AEO), Additional Agriculture Officer (AAO) and Upazila Agriculture Officer (UAO). Prior to data collection, the pre-tested questionnaire was explained along with proper guidelines to the AEOs or UAOs or both and handed over to them at each Deputy Director's office of Department of Agricultural Extension (DAE) during monthly meeting. The filled questionnaires were collected by the scientists of Rice Farming Systems Division, checked and analyzed to find the inconsistencies of the supplied data before validation workshop. All the inconsistencies among the information were documented. The collected data along with documented inconsistencies were discussed in district level workshop to for necessary correction and validation. Second stage of data collection was daylong data validation workshop at district level. The workshop held on the 27 August in Munsijganj; 7 September in Gazipur; 17 September in Manikganj; 21 September in Narsingdi; 5 October in Dhaka 3 November in Tangail; and 25 November 2015 in Narayanganj district. Four field-workers i.e. one SAPPO and three SAAOs experienced and engaged in crop-based data documentation, all officers from all upazilas viz UAOs, AEOs, AAEOs, DD (DAE), DD (Horticulture), Deputy Director of Seed Certification Agency, District Training Officer and Additional Deputy Directors, one representative from Agricultural Training Institute (ATI) participated in the data validation workshop. The number participants of validation workshop ranged from 46 to 104 in each district. All the participants were divided into three to four groups for data validation. 
Each group was facilitated by two scientists to finalize and validate the data and authenticated data were captured. Crop diversity index was calculated by using the following equation described by Kshirsagar et al. (1997).

$$
C D I_{i}=1-\sum_{j=o}^{n}\left(\frac{a_{i j}}{A_{i}}\right)^{2}
$$

Where, $\mathrm{CDI}_{\mathrm{i}}=$ Crop Diversity Index

$a_{i j}=$ Area planted to the $j^{\text {th }}$ crop in the $i^{\text {th }}$ location

$A_{i}=$ Total area planted under all crops

The index is zero for a land area growing only one crop. It approaches unity as the level of diversity increases. Compilation and processing of the collected data were done using Microsoft Excel programme. Descriptive statistics were used to facilitate the presentation of the findings.

\section{RESULTS AND DISCUSSION}

\section{Land use}

Table 1 presents the status of agricultural land utilization in Dhaka region. The net cropped area of the region is 653,670 hectares. Crops occupied the particular land for round the year were considered under annual crops. The major annual crops reported in the region were pineapple, sugarcane, banana papaya, betel leaf, ginger and turmeric. The annual cropped area in different upazilas ranged from 10 to 11,000 ha. The annual cropped area accounted only 5.21\% of the net cropped area (NCA) in the region. At a glance, the region possesses $21.25 \%$ single cropped area (SCA), 55.37\% double cropped area (DCA), $17.23 \%$ triple cropped area (TCA) and $0.04 \%$ quadruple cropped area (QCA). The SCA had the major share of NCA in Raipur upazila of Narsingdi district, Sreepur and Kaliganj upazilas of Gazipur district; Sreenagar upazila of Munsiganj district; Nawabganj and Savar upazilas of Dhaka district, Rupganj and Sonargaon upazila of Narayanganj district followed by corresponding double cropped area (DCA). Most of the upazilas were dominated by DCA (Table 1). The area which could not defined under SCA, DCA, TCA or QCA was considered as others whose coverage is less than $1 \%$ of the NCA.

\section{Cropping patterns of Dhaka}

In total, 164 cropping patterns were observed in Dhaka region of which eight cropping patterns with exclusive rice crop covers $48 \%$ of the NCA. There were 59 cropping patterns with exclusive non-rice crop covering about $16 \%$ of the NCA. Rest of the NCA i.e. around 25\% area is covered by 97 rice - non-rice cropping patterns (Appendix 1).

\section{Rice and non-rice crops at a glance}

Table 2 presents eight cropping patterns where rice is the only crop round the year. It comprises $48.27 \%$ of the NCA in the region. Among them single, double and triple rice areas represent $18.88 \%, 29.20 \%$ and $0.19 \%$, respectively. It reflects the unparallel dominance of rice in the cropping systems in Dhaka region. In case of individual pattern Boro-Fallow-T. Aman has the highest coverage (22.59\%) and was recorded in 32 upazilas out of 46 . The second dominant pattern as single Boro area occupied 16.74\% of NCA which was distributed in most of the upazilas i.e. 44 upazilas. Boro-B.Aman covered $6.12 \%$ area with its considerable existence in 24 upazilas.

In the current investigation, 59 cropping patterns were identified that was free from rice. Among the 59 patterns first 47 have been arranged in descending order in Table 3. The rest 12 patterns with negligible area coverage can be found in Table 8 where they are arranged with other patterns of different categories. Aggregate of the 59 patterns have had approximately $16 \%$ of NCA. In critical comparison is clear that exclusive rice area is about three folds of exclusive non-rice area. In Dhaka region crop diversity is much wider than that of other regions like Sylhet and Chittagong where exclusive rice area covers 37 folds and 23 folds, respectively, of exclusive non-rice area (Muttaleb et al., 2017; Shahidullah et al., 2017). Appropriate cropping patterns may facilitate maximum possible land utilization as well as efficient use of other scarce resources 
Table 1. Land use of different upazilas in Dhaka region (area in hectare), 2014-15.

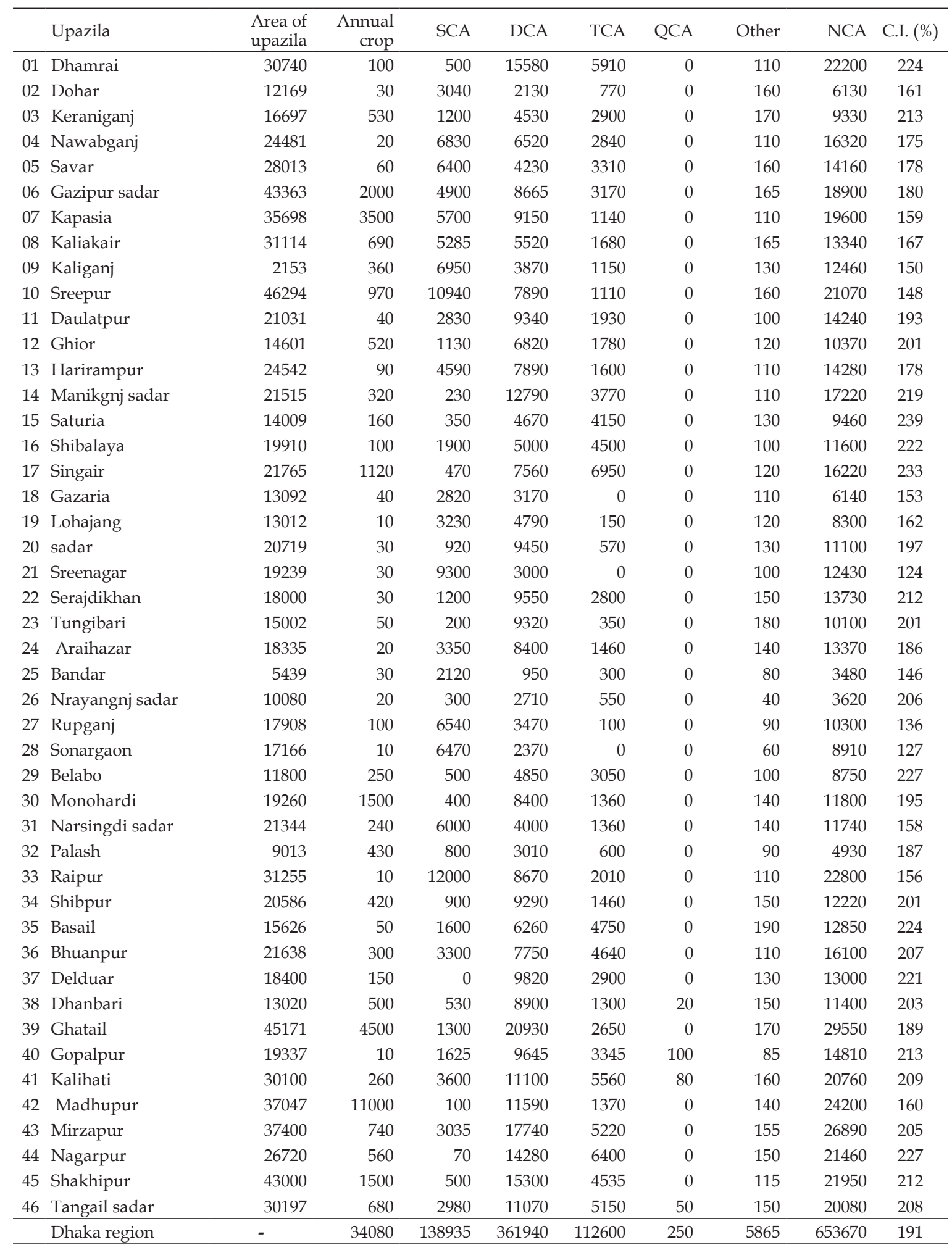

126 Parvin et al 
Table 2. Cropping patterns with exclusive rice in Dhaka region, 3014-15.

\begin{tabular}{llrrc}
\hline & Cropping pattern & Area (ha) & \% of NCA & Frequency (no. of upazila) \\
\hline 01 & Boro-Fallow-T. Aman & 147820 & 22.61 & 32 \\
02 & Boro-Fallow-Fallow & 109530 & 16.76 & 44 \\
03 & Boro-B.Aman & 40050 & 6.13 & 24 \\
04 & Fallow-Fallow-T. Aman & 9650 & 1.48 & 5 \\
05 & Boro-Sesbania-Fallow & 4410 & 0.67 & 7 \\
06 & Boro-Sesbania-T. Aman & 2440 & 0.37 & 6 \\
07 & Boro-Aus-T. Aman & 1215 & 0.19 & 7 \\
08 & Boro-Aus-Fallow & 780 & 0.12 & 6 \\
\hline & Total & 315895 & 48.33 & \\
\hline
\end{tabular}

in a sustainable manner. Diversified cropping pattern may be option for the farmers as a coping strategy against risks (Mandal and Bezbaruah, 2013). Typology of different cropping systems is the base for the managers of these systems to intensify production (Shriar, 2000).

\section{Deep water rice ecosystem}

Deep water is a special type of ecosystem in the country. In context of Dhaka region this ecosystem represents a large portion. The cropping patterns under deep water ecosystem are listed in the Table 4. Among the listed 20 patterns Boro-B.Aman cropping pattern covers the highest area coverage of 40,050 hectares which represents $6.12 \%$ of the region's NCA. This pattern is distributed over 24 upazilas out of 46. The second highest Mustard-Boro-B. Aman cropping pattern covers 26,600 hectares and distributed over 21 upazilas. The first two patterns jointly covered $10.18 \%$ NCA which is more than three-fifths of total deep-water irce area in the region. The water level of this ecosystem ranges between 150 and $400 \mathrm{~cm}$, and water usually remains 3-4 months. Special rice varieties known as 'floating rice' are planted in these areas. In the past, Bangladesh had a land coverage of 3 million hectares for deepwater rice (Jackson et al., 1972). In course of time the continuous effort on modern agriculture shifted DWR area mainly to modern Boro. Now, the area under deep water rice in Bangladesh is reduced to 0.4 million hectares (Nasim et al., 2017). Though this cropping system is less productive than other modern cropping systems, the specific fragile ecosystem still struggling because of no other alternatives.

\section{Vegetables and spices crops}

Seventy-six cropping patterns have been arranged in descending order according to area coverage in Table 5. Potato, sweet potato, vegetables of Rabi, Kharif-I and Kharif-II; spices viz chilli, onion, garlic are included in this list. A row is included at the end of the Table 5 representing an aggregate of 19 patterns of vegetables and spices, which is elaborately presented in the Table 8 with other patterns of different categories. The most contributing cropping pattern is year-round vegetables covering $3.98 \%$ of NCA, which distributed over 36 upazilas. Potato-B.Aman was the second dominant cropping pattern which possessed 19,960 ha covering $3.05 \%$ of NCA and recorded in 15 upazilas. Potao-Sesbania is the third dominant pattern exists in 13 upazilas. Among the vegetables potato alone is leading in 20 cropping patterns covering 49,550 hectares of land, which is equivalent to $7.57 \%$ of NCA. For availability of irrigation water in dry season, supply of modern varieties of various crops, skilled technology transfer system, knowledge on modern crop management practices, high market value of fresh vegetables, good communication and marketing facilities enhanced the extensive production of various types of vegetables in Dhaka region (FAO, 1988). Vegetables like Colocasia esculenta, okra (Abelmoschus esculentus), amaranth (Amaranthus spp.), brinjal (Solanum melongena), cucurbits, etc are grown in medium upland adjacent to rice fields during rainy season and potato, sweet gourd, cole crops, leafy vegetables etc are grown during winter season in Tripura (Das et.al., 2015). 
Table 3. Cropping patterns of non-rice exclusive in Dhaka region, 2014-15.

\begin{tabular}{|c|c|c|c|c|}
\hline & Cropping pattern & Area (ha) & $\%$ of NCA & Frequency (no. of upazila) \\
\hline 01 & Vegetab-Vegetab-Vegetab & 26050 & 3.99 & 36 \\
\hline 02 & Potato-Sesbania & 10220 & 1.56 & 13 \\
\hline 03 & Vegetab-Vegetab-Fallow & 8750 & 1.34 & 17 \\
\hline 04 & Vegetab-Fallow-Fallow & 6980 & 1.07 & 9 \\
\hline 05 & Potato-Jute-Fallow & 4360 & 0.67 & 15 \\
\hline 06 & Groundnut-Fallow-Fallow & 3620 & 0.55 & 8 \\
\hline 07 & Fallow-Fallow-Blackgram & 3415 & 0.52 & 10 \\
\hline 08 & Maize-Maize-Fallow & 3280 & 0.50 & 3 \\
\hline 09 & Maize-Jute-Fallow & 2790 & 0.43 & 6 \\
\hline 10 & Maize-Fallow-Fallow & 2265 & 0.35 & 6 \\
\hline 11 & Vegetab-Jute-Fallow & 2170 & 0.33 & 10 \\
\hline 12 & Sesame-Fallow-Blackgram & 1850 & 0.28 & 4 \\
\hline 13 & Maize-Vegetab-Fallow & 1700 & 0.26 & 5 \\
\hline 14 & Wheat-Jute-Fallow & 1560 & 0.24 & 10 \\
\hline 15 & Chilli-Fallow-Fallow & 1490 & 0.23 & 6 \\
\hline 16 & S.Potato-Fallow-Fallow & 1430 & 0.22 & 9 \\
\hline 17 & Potato-Sesame-Fallow & 1390 & 0.21 & 8 \\
\hline 18 & Grasspea-Sesbania-Fallow & 1350 & 0.21 & 2 \\
\hline 19 & Onion-Jute-Fallow & 1350 & 0.21 & 11 \\
\hline 20 & S.Potato-Jute-Fallow & 1230 & 0.19 & 7 \\
\hline 21 & Vegetab-Maize-Fallow & 1170 & 0.18 & 3 \\
\hline 22 & Grasspea-Fallow-Fallow & 1060 & 0.16 & 3 \\
\hline 23 & Chilli-Jute-Fallow & 1050 & 0.16 & 11 \\
\hline 24 & Lentil-Jute-Fallow & 1040 & 0.16 & 8 \\
\hline 25 & Maize-Sesbania-Fallow & 1000 & 0.15 & 1 \\
\hline 26 & Grasspea-Sesame-Fallow & 920 & 0.14 & 6 \\
\hline 27 & Onion-Vegtab-Vegetab & 800 & 0.12 & 9 \\
\hline 28 & Vegetab-Fallow-Blackgram & 790 & 0.12 & 4 \\
\hline 29 & Maize-Sesame-Fallow & 690 & 0.11 & 2 \\
\hline 30 & Blackgram-Jute-Fallow & 660 & 0.10 & 2 \\
\hline 31 & Potato-Maize-Fallow & 610 & 0.09 & 4 \\
\hline 32 & Coriander-Vegetab-Fallow & 580 & 0.09 & 3 \\
\hline 33 & Chilli-Vegetab-Fallow & 570 & 0.09 & 7 \\
\hline 34 & Mustard-Jute-Fallow & 560 & 0.09 & 4 \\
\hline 35 & Garlic-Jute-Fallow & 530 & 0.08 & 9 \\
\hline 36 & Grasspea-Jute-Fallow & 420 & 0.06 & 3 \\
\hline 37 & Coriander-Fallow-Fallow & 390 & 0.06 & 6 \\
\hline 38 & Lentil-Sesame-Fallow & 355 & 0.05 & 3 \\
\hline 39 & Pea-Vegetab-Fallow & 350 & 0.05 & 1 \\
\hline 40 & Coriander-Jute-Fallow & 330 & 0.05 & 6 \\
\hline 41 & Potato-Chilli-Fallow & 330 & 0.05 & 3 \\
\hline 42 & Lentil-Vegetab-Vegetab & 320 & 0.05 & 4 \\
\hline 43 & Potato-Groundnut & 170 & 0.03 & 1 \\
\hline 44 & Garlic-Fallow-Fallow & 150 & 0.02 & 3 \\
\hline 45 & Maize-Fallow-Blackgram & 150 & 0.02 & 1 \\
\hline 46 & Garlic-Vegetab-Vegetab & 135 & 0.02 & 5 \\
\hline 47 & Wheat-Chilli-Fallow & 110 & 0.02 & 1 \\
\hline \multirow[t]{2}{*}{$48-59$} & Other 12 patterns (in Table 8) & 575 & 0.09 & - \\
\hline & Total area for exclusive non-rice & 103065 & 15.77 & \\
\hline
\end{tabular}


Table 4. Cropping patterns under deep water rice ecosystem in Dhaka region, 2014-15.

\begin{tabular}{|c|c|c|c|c|}
\hline & Cropping pattern & Area (ha) & $\%$ of NCA & Frequency (no. of upazila) \\
\hline 01 & Boro-B.Aman & 40050 & 6.13 & 24 \\
\hline 02 & Mustard-Boro-B.Aman & 26600 & 4.07 & 21 \\
\hline 03 & Potato-B.Aman & 19960 & 3.05 & 15 \\
\hline 04 & Onion-B.Aman & 5230 & 0.80 & 8 \\
\hline 05 & Blackgram-B.Aman & 3090 & 0.47 & 8 \\
\hline 06 & Grasspea-B.Aman & 2970 & 0.45 & 11 \\
\hline 07 & Maize-B.Aman & 1920 & 0.29 & 7 \\
\hline 08 & Vegetab-B.Aman & 1690 & 0.26 & 6 \\
\hline 09 & Mustard-B.Aman & 1340 & 0.20 & 4 \\
\hline 10 & Chilli-B.Aman & 820 & 0.13 & 6 \\
\hline 11 & Mustard-Sesame+B.Aman & 800 & 0.12 & 2 \\
\hline 12 & Wheat-B.Aman & 690 & 0.11 & 7 \\
\hline 13 & Garlic-B.Aman & 640 & 0.10 & 5 \\
\hline 14 & Sesame+B.Aman-Blackgram & 600 & 0.09 & 1 \\
\hline 15 & Coriander-B.Aman & 550 & 0.08 & 6 \\
\hline 16 & Groundnut-B.Aman & 420 & 0.06 & 4 \\
\hline 17 & Lentil-B.Aman & 330 & 0.05 & 5 \\
\hline 18 & Grasspea-B.Aus+B.Aman & 300 & 0.05 & 1 \\
\hline 19 & Potato+Maize-B.Aman & 300 & 0.05 & 1 \\
\hline 20 & Fallow-Sesame+B.Aman & 200 & 0.03 & 2 \\
\hline 21 & Pea-B.Aman & 170 & 0.03 & 4 \\
\hline \multirow[t]{2}{*}{$22-24$} & Other three patterns (in Table 8) & 280 & 0.04 & \\
\hline & Total deep-water rice & 108950 & 16.67 & \\
\hline
\end{tabular}

\section{Oil-seed crops}

Mustard is the most important one among the oil-seed crops in Dhaka region. There are 32 cropping patterns for oil-seeds among which 15 patterns had been led by mustard alone (Tables 6 and 8). The total share of oil-seed cropping patterns is $17.71 \%$ of NCA in the region whereas mustard absolutely occupies $16.11 \%$. The second prevailing sesame covers over $1 \%$. The most dominant Mustard-Boro-Fallow pattern is distributed over 31 upazilas out of 46 .

\section{Pulse crops}

Thirty-four cropping patterns are holding different pulse crops (Tables 7 and 8). Among them blackgram is covering the largest area whereas pea is cultivated in the smallest area. Twelve cropping patterns of blackgram jointly cover $2.42 \%$ of NCA. Grasspea (Lathyrus satious) holds the second position in pulse crop cultivation in Dhaka region. There are nine cropping patterns for grasspea, which in-together occupy about $1 \%$ of NCA. In the documentation of pulse cropping systems grasspea has the widest spreading in the region. The third ranking pattern Grasspea-B. Aman is available in 11 upazilas. Finally the aggregate area of the pulse cropping system stands for $4.26 \%$ of the NCA in Dhaka region. The rapid increase in human population creates additional pressure on natural resources at above optimal levels of their inherent potential, which resulted the loss of biodiversity, serious soil erosion leading to depletion of plant nutrient, gradual degradation and decline in productivity and carrying capacity (FAO, 1988).

\section{Sporadic and distinct cropping patterns}

Some cropping patterns are extremely locationspecific, however, with a large area coverage. These are Maize-Maize-Fallow (Table 3) and Vegetable-Boro-Fallow (Table 5). The MaizeMaize-Fallow is grown in Ghior (430 ha), Saturia (1,700 ha) and Singair (1,150 ha) upazila in Manikganj district. Vegetable-Boro-Fallow is limited to only Dhamrai upazila (1,590 ha) 
Table 5. Area for vegetables and spices under different cropping patterns in Dhaka region, 2014-15.

\begin{tabular}{|c|c|c|c|}
\hline Cropping pattern & Area (ha) & $\%$ of NCA & Frequency (no. of upazila) \\
\hline 01 Vegetab-Vegetab-Vegetab & 26050 & 3.98 & 36 \\
\hline 02 Potato-B.Aman & 19960 & 3.05 & 15 \\
\hline 03 Potato-Sesbania & 10220 & 1.56 & 13 \\
\hline 04 Vegetab-Vegetab-Fallow & 8750 & 1.34 & 17 \\
\hline 05 Vegetab-Fallow-Fallow & 6980 & 1.07 & 9 \\
\hline 06 Onion-B.Aman & 5230 & 0.80 & 8 \\
\hline 07 Potato-Jute-Fallow & 4360 & 0.67 & 15 \\
\hline 08 Potato-Boro-Fallow & 4050 & 0.62 & 5 \\
\hline 09 Potato-Jute-T. Aman & 3360 & 0.51 & 14 \\
\hline 10 Potato-Boro-T. Aman & 3090 & 0.47 & 11 \\
\hline 11 Vegetab-Boro-Fallow & 2590 & 0.40 & 2 \\
\hline 12 Boro-Vegetab(Float/Norm) & 2360 & 0.36 & 5 \\
\hline 13 Vegetab-Jute-Fallow & 2170 & 0.33 & 10 \\
\hline 14 Maize-Vegetab-Fallow & 1700 & 0.26 & 5 \\
\hline 15 Vegetab-B.Aman & 1690 & 0.26 & 6 \\
\hline 16 Vegetab-Vegetab-T. Aman & 1660 & 0.25 & 6 \\
\hline 17 Chilli-Fallow-Fallow & 1490 & 0.23 & 6 \\
\hline 18 S.Potato-Fallow-Fallow & 1430 & 0.22 & 9 \\
\hline 19 Potato-Sesame-Fallow & 1390 & 0.21 & 8 \\
\hline 20 Onion-Jute-Fallow & 1350 & 0.21 & 11 \\
\hline 21 S.Potato-Jute-Fallow & 1230 & 0.19 & 7 \\
\hline 22 Boro-Vegetab-T. Aman & 1200 & 0.18 & 1 \\
\hline 23 Vegetab-Maize-Fallow & 1170 & 0.18 & 3 \\
\hline 24 Vegetab-Jute-T. Aman & 1120 & 0.17 & 7 \\
\hline 25 Chilli-Jute-Fallow & 1050 & 0.16 & 11 \\
\hline 26 Chilli-B.Aman & 820 & 0.13 & 6 \\
\hline 27 Vegetab-Boro-T. Aman & 820 & 0.13 & 5 \\
\hline 28 Onion-Vegtab-Vegetab & 800 & 0.12 & 9 \\
\hline 29 Vegetab-Fallow-Blackgram & 790 & 0.12 & 4 \\
\hline 30 Fallow-Vegetab-T. Aman & 720 & 0.11 & 1 \\
\hline 31 Vegetab-Aus-T. Aman & 680 & 0.10 & 3 \\
\hline 32 Garlic-B.Aman & 640 & 0.10 & 5 \\
\hline 33 Potato-Maize-Fallow & 610 & 0.09 & 4 \\
\hline 34 Coriander-Vegetab-Fallow & 580 & 0.09 & 3 \\
\hline 35 Chilli-Vegetab-Fallow & 570 & 0.09 & 7 \\
\hline 36 Coriander-B.Aman & 550 & 0.08 & 6 \\
\hline 37 Garlic-Jute-Fallow & 530 & 0.08 & 9 \\
\hline 38 Onion-Jute-T. Aman & 530 & 0.08 & 5 \\
\hline 39 Potato-Vegetab-T. Aman & 440 & 0.07 & 5 \\
\hline 40 Chilli-Fallow-T. Aman & 400 & 0.06 & 2 \\
\hline 41 Potato-Fallow-T. Aman & 400 & 0.06 & 1 \\
\hline 42 Potato-Maize-T. Aman & 400 & 0.06 & 2 \\
\hline 43 Coriander-Fallow-Fallow & 390 & 0.06 & 6 \\
\hline 44 Vegetab-Fallow-T. Aman & 360 & 0.06 & 4 \\
\hline 45 Pea-Vegetab-Fallow & 350 & 0.05 & 1 \\
\hline 46 Coriander-Jute-Fallow & 330 & 0.05 & 6 \\
\hline 47 Potato-Chilli-Fallow & 330 & 0.05 & 3 \\
\hline 48 Lentil-Vegetab-Vegetab & 320 & 0.05 & 4 \\
\hline 49 Potato+Maize-B.Aman & 300 & 0.05 & 1 \\
\hline 50 Potato-Sesame-Aus & 200 & 0.03 & 1 \\
\hline 51 Potato-Groundnut & 170 & 0.03 & 1 \\
\hline 52 Chilli-Vegetab-T. Aman & 150 & 0.02 & 1 \\
\hline 53 Garlic-Fallow-Fallow & 150 & 0.02 & 3 \\
\hline 54 Garlic-Vegetab-Vegetab & 135 & 0.02 & 5 \\
\hline 55 Garlic-Jute-T. Aman & 110 & 0.02 & 4 \\
\hline 56 Potato-Aus-Fallow & 110 & 0.02 & 2 \\
\hline 57 Wheat-Chilli-Fallow & 110 & 0.02 & 1 \\
\hline 58-76 Other 19 patterns (in Table 8) & 1030 & 0.16 & - \\
\hline Total vegetab. and spices & 130475 & 19.94 & \\
\hline
\end{tabular}

130 Parvin et al 
Table 6. Area coverage for oil-seed crops under different cropping patterns in Dhaka region, 2014-15.

\begin{tabular}{|c|c|c|c|c|}
\hline & Cropping pattern & Area (ha) & $\%$ of NCA & Frequency (no. of upazila) \\
\hline 01 & Mustard-Boro-Fallow & 51300 & 7.84 & 31 \\
\hline 02 & Mustard-Boro-B.Aman & 26600 & 4.06 & 21 \\
\hline 03 & Mustard-Boro-T. Aman & 22400 & 3.42 & 26 \\
\hline 04 & Groundnut-Fallow-Fallow & 3620 & 0.55 & 8 \\
\hline 05 & Sesame-Fallow-Blackgram & 1850 & 0.28 & 4 \\
\hline 06 & Potato-Sesame-Fallow & 1390 & 0.21 & 8 \\
\hline 07 & Mustard-B.Aman & 1340 & 0.20 & 4 \\
\hline 08 & Mustard-Boro-Jute & 1100 & 0.17 & 5 \\
\hline 09 & Grasspea-Sesame-Fallow & 920 & 0.14 & 6 \\
\hline 10 & Mustard-Sesame+B.Aman & 800 & 0.12 & 2 \\
\hline 11 & Mustard-Boro-Sesbania & 700 & 0.11 & 2 \\
\hline 12 & Maize-Sesame-Fallow & 690 & 0.11 & 2 \\
\hline 13 & Sesame+B.Aman-Blackgram & 600 & 0.09 & 1 \\
\hline 14 & Mustard-Jute-Fallow & 560 & 0.09 & 4 \\
\hline 15 & Groundnut-B.Aman & 420 & 0.06 & 4 \\
\hline 16 & Lentil-Sesame-Fallow & 355 & 0.05 & 3 \\
\hline 17 & Mustard-Boro-Jute-T. Aman & 240 & 0.04 & 4 \\
\hline 18 & Mustard-Jute-T. Aman & 220 & 0.03 & 3 \\
\hline 19 & Fallow-Sesame+B.Aman & 200 & 0.03 & 2 \\
\hline 20 & Potato-Sesame-Aus & 200 & 0.03 & 1 \\
\hline 21 & Potato-Groundnut & 170 & 0.03 & 1 \\
\hline \multirow[t]{2}{*}{$22-32$} & Other 11 patterns (in Table 8) & 490 & 0.07 & \\
\hline & Total oil-seed crops & 116165 & 17.77 & \\
\hline
\end{tabular}

in Dhaka and Singair (1,000 ha) upazila in Manikganj district.

\section{Rare cropping patterns}

In the present investigation, 45 cropping patterns have been identified as rare cropping patterns with a negligible area coverage with seldom existence (Table 8). These are location specific system and are limited in one or two upazilas of the region. Total area coverage of the 45 patterns is only $0.35 \%$ of NCA. Among these the top nine patterns are holding the same area i.e. 100 ha for each. The smallest area was recorded for Millet (cheena)-Fallow-Fallow cropping pattern whose coverage was only 5 hectares (Table 7) and is available only in Mirzapur upazila of Tangail district.

\section{Most dominant cropping pattern}

Boro-Fallow-T. Aman was the most dominant cropping pattern in Dhaka region. It covers $22.59 \%$ of NCA in the region and is available in 32 upazilas out of 46 (Table 9). The highest area under this cropping was recorded 18,000 hectares in Ghatail upazila of Tangail district, which represents $12.18 \%$ of the total Boro-Fallow-T. Aman area of the region. In consideration of individual upazila Dhanbari stands on the sixth position for area coverage of the pattern, however, this upazila has allocated highest area and it is $79.16 \%$ of its NCA for this pattern alone. Keraniganj and Dohar upazila of Dhaka district and Narayanganj sadar upazila had a negligible area coverage for this pattern. In the country-wide compilation of data it was observed that Boro-F-T. Aman was the most dominant cropping pattern in Bangladesh covering 2.31 million ha $(27 \%$ of NCA in the country) with its distribution in 426 upazilas of 63 districts (Nasim et al., 2017).

\section{Second dominant cropping pattern}

The second dominant cropping pattern in Dhaka region is the single Boro. It belongs to $16.74 \%$ NCA of the region and spread out over most of the upazilas i.e. 44 upazilas (Table 10). 
Table 7. Area coverage for pulse crops under different cropping systems in Dhaka region, 2014-15.

\begin{tabular}{|c|c|c|c|c|}
\hline & Cropping pattern & Area (ha) & $\%$ of NCA & Frequency (no. of upazila) \\
\hline 01 & Boro-Fallow-Blackgram & 3955 & 0.60 & 9 \\
\hline 02 & Fallow-Fallow-Blackgram & 3415 & 0.52 & 10 \\
\hline 03 & Blackgram-B.Aman & 3090 & 0.47 & 8 \\
\hline 04 & Grasspea-B.Aman & 2970 & 0.45 & 11 \\
\hline 05 & Sesame-Fallow-Blackgram & 1850 & 0.28 & 4 \\
\hline 06 & Grasspea-Sesbania-Fallow & 1350 & 0.21 & 2 \\
\hline 07 & Grasspea-Jute-T. Aman & 1150 & 0.18 & 2 \\
\hline 08 & Lentil-Jute-T. Aman & 1120 & 0.17 & 4 \\
\hline 09 & Grasspea-Fallow-Fallow & 1060 & 0.16 & 3 \\
\hline 10 & Lentil-Jute-Fallow & 1040 & 0.16 & 8 \\
\hline 11 & Grasspea-Sesame-Fallow & 920 & 0.14 & 6 \\
\hline 12 & Blackgram-Aus-T. Aman & 850 & 0.13 & 2 \\
\hline 13 & Vegetab-Fallow-Blackgram & 790 & 0.12 & 4 \\
\hline 14 & Blackgram-Jute-Fallow & 660 & 0.10 & 2 \\
\hline 15 & Sesame+B.Aman-Blackgram & 600 & 0.09 & 1 \\
\hline 16 & Grasspea-Jute-Fallow & 420 & 0.06 & 3 \\
\hline 17 & Lentil-Sesame-Fallow & 355 & 0.05 & 3 \\
\hline 18 & Blackgram-Jute-T. Aman & 350 & 0.05 & 2 \\
\hline 19 & Pea-Vegetab-Fallow & 350 & 0.05 & 1 \\
\hline 20 & Lentil-B.Aman & 330 & 0.05 & 5 \\
\hline 21 & Lentil-Vegetab-Vegetab & 320 & 0.05 & 4 \\
\hline 22 & Grasspea-B.Aus+B.Aman & 300 & 0.05 & 1 \\
\hline 23 & Pea-B.Aman & 170 & 0.03 & 4 \\
\hline 24 & Maize-Fallow-Blackgram & 150 & 0.02 & 1 \\
\hline \multirow[t]{2}{*}{$25-34$} & Other 10 patterns (in Table 8) & 570 & 0.09 & \\
\hline & Total pulse crops & 28135 & 4.30 & \\
\hline
\end{tabular}

Sreenagar upazila of Munsiganj district holding the highest is $(9,300 \mathrm{ha})$ under this single Boro cropping. This upazila alone contribute $8.49 \%$ share of single Boro cropping area in the region. This upazila has allotted its largest share $(74.82 \%)$ of NCA. Sonargaon upazila of Narayanganj has maintained the $8^{\text {th }}$ position for single Boro area coverage (5,400 ha) in the region. However, this area represents $60.61 \%$ of its own NCA. This pattern is frequent and concurrently experienced by early flash flood in April and cold injury at reproductive stage. Diversified cropping pattern may be resort for the farmer as a coping strategy with flood related risk (Mandal and Bezbaruah, 2013) but scope of diversification is limited due to environmental and climatic condition (FAO, 1988). In the country-wide compilation of data it was observed that the single Boro was the second dominant cropping pattern in Bangladesh covering 1.14 million ha (13\% of
NCA in the country) with its distribution in 342 upazilas of 59 districts (Nasim et al., 2017).

\section{Third dominant cropping pattern}

Mustard-Boro-Fallow cropping pattern holds the third largest area coverage 51,300 hectares in Dhaka region. This area is an equivalent to $7.84 \%$ of NCA in the region. This pattern Mustard-Boro-Fallow is widely distributed over 31 upazilas. Manikganj sadar upazila has an area of 6,100 ha for this pattern which stands for $11.89 \%$ of the total area under this pattern in the region (Table 11). Ghior upazila of Manikganj district ranks in third position for Mustard-Boro-Fallow, however, this upazila has allotted the largest share (41.44\%) of NCA.

\section{Fourth dominant cropping pattern}

Fourth dominant cropping pattern Boro-B. Aman has occupied 40,050 hectares representing $6.12 \%$ share of NCA in Dhaka region (Table 12). 
Table 8. Rare cropping patterns covering non-significant area in Dhaka region, 2014-15.

\begin{tabular}{|c|c|c|c|c|c|}
\hline & Cropping pattern & Area (ha) & $\%$ of NCA & Frequency & Upazila \\
\hline 01 & Tobacco-Jute-Fallow & 100 & 0.02 & 2 & Daulatpur+Ghior \\
\hline 02 & Vegetab-Aus-Blackgram & 100 & 0.02 & 2 & Saturia+Shibpur \\
\hline 03 & Wheat-Vegetab-T. Aman & 100 & 0.02 & 2 & Madhupur+Nagarpur \\
\hline 04 & Garlic-Fallow-T. Aman & 100 & 0.02 & 1 & Belabo \\
\hline 05 & Grasspea-Boro-B.Aman & 100 & 0.02 & 1 & Dohar \\
\hline 06 & Grasspea-Sesame+B.Aman & 100 & 0.02 & 1 & Singair \\
\hline 07 & Maize-Aus-T. Aman & 100 & 0.02 & 1 & Dhamrai \\
\hline 08 & Potato-Boro-Vegetab & 100 & 0.02 & 1 & Saturia \\
\hline 09 & Wheat-Sesame-Fallow & 100 & 0.02 & 1 & Delduar \\
\hline 10 & Coriander-Jute-T. Aman & 90 & 0.01 & 1 & Dhamrai \\
\hline 11 & Mungbean-Fallow-T. Aman & 80 & 0.01 & 3 & Sreepur+Belabo+Shibpur \\
\hline 12 & Mustard-Aus-T. Aman & 80 & 0.01 & 1 & Dhamrai \\
\hline 13 & S.Potato-B.Aman & 80 & 0.01 & 1 & Araihazar \\
\hline 14 & Tobacco-Fallow-Fallow & 80 & 0.01 & 1 & Daulatpur \\
\hline 15 & Coriander-Fallow-T. Aman & 70 & 0.01 & 1 & Belabo \\
\hline 16 & Wheat-Aus-T. Aman & 65 & 0.01 & 4 & Sreepur+Raipur+Araihazar \\
\hline 17 & Mustard-Aus-Fallow & 50 & 0.01 & 2 & Dohar+Keraniganj \\
\hline 18 & Wheat-Sesame-T. Aman & 50 & 0.01 & 2 & Kalihati+Tangail \\
\hline 19 & Boro-Aus-Blackgram & 50 & 0.01 & 1 & Basail \\
\hline 20 & Onion-Sesame-Fallow & 50 & 0.01 & 1 & Kalihati \\
\hline 21 & Vegetab-Jute-Vegetab & 50 & 0.01 & 1 & Madhupur \\
\hline 22 & Wheat-Aus-Fallow & 50 & 0.01 & 1 & Tangail \\
\hline 23 & Grasspea-Boro-Fallow & 40 & 0.01 & 2 & Dhamrai+Keraniganj \\
\hline 24 & S.Potato-Jute-T. Aman & 40 & 0.01 & 2 & Belabo+Kalihati \\
\hline 25 & Chilli-Aus-Fallow & 40 & 0.01 & 1 & Tungibari \\
\hline 26 & Onion-Maize-Fallow & 40 & 0.01 & 1 & Ghior \\
\hline 27 & Potato-Maize-Vegetab & 40 & 0.01 & 1 & Ghior \\
\hline 28 & Vegetab-Aus-Fallow & 40 & 0.01 & 1 & Keraniganj \\
\hline 29 & Wheat-Jute-Blackgram & 40 & 0.01 & 1 & Singair \\
\hline 30 & Lentil-Aus-Fallow & 30 & 0.00 & 2 & Dhamrai+Tungibari \\
\hline 31 & Wheat-Vegetab-Vegetab & 30 & 0.00 & 1 & Singair \\
\hline 32 & Wheat-Jute-Vegetab & 20 & 0.00 & 2 & Savar+Narsingdi \\
\hline 33 & Lentil-Fallow-T. Aman & 20 & 0.00 & 1 & Kaliganj \\
\hline 34 & Mustard-Fallow-T. Aman & 20 & 0.00 & 1 & Gazipur \\
\hline 35 & Onion-Aus-Fallow & 20 & 0.00 & 1 & Lohajang \\
\hline 36 & Wheat-Fallow-Fallow & 20 & 0.00 & 1 & Gopalpur \\
\hline 37 & Grasspea-Fallow-T. Aman & 10 & 0.00 & 1 & Kaliganj \\
\hline 38 & Groundnut-Jute-T. Aman & 10 & 0.00 & 1 & Belabo \\
\hline 39 & Mustard-Boro-Aus-T. Aman & 10 & 0.00 & 1 & Tangail \\
\hline 40 & Mustard-Sesame-T. Aman & 10 & 0.00 & 1 & Belabo \\
\hline 41 & Potato-Sesame-T. Aman & 10 & 0.00 & 1 & Belabo \\
\hline 42 & Potato+S.gourd-Aus-T. Aman & 10 & 0.00 & 1 & Gopalpur \\
\hline 43 & Tobacco-Jute-T. Aman & 10 & 0.00 & 1 & Daulatpur \\
\hline 44 & Wheat-Fallow-T. Aman & 10 & 0.00 & 1 & Sreepur \\
\hline \multirow[t]{2}{*}{45} & Millet (cheena)-Fallow-Fallow & 5 & 0.00 & 1 & Mirzapur \\
\hline & Total & 2270 & 0.35 & & - \\
\hline
\end{tabular}


Table 9. Distribution of the most dominant Boro-F-T. Aman cropping patterns in the region, 2014-15.

\begin{tabular}{|c|c|c|c|c|}
\hline & Upazila & Area (ha) & $\%$ of upazila NCA & $\%$ of the pattern in region \\
\hline 01 & Ghatail & 18000 & 60.91 & 12.18 \\
\hline 02 & Shakhipur & 14000 & 63.78 & 9.47 \\
\hline 03 & Madhupur & 11500 & 45.73 & 7.78 \\
\hline 04 & Gopalpur & 9400 & 63.26 & 6.36 \\
\hline 05 & Shibpur & 8800 & 72.01 & 5.95 \\
\hline 06 & Dhanbari & 8700 & 79.16 & 5.89 \\
\hline 07 & Monohardi & 8400 & 71.19 & 5.68 \\
\hline 08 & Kapasia & 8200 & 41.71 & 5.55 \\
\hline 09 & Sreeppur & 6500 & 30.85 & 4.40 \\
\hline 10 & Kalihati & 6500 & 31.31 & 4.40 \\
\hline 11 & Gazipur & 6100 & 32.28 & 4.13 \\
\hline 12 & Raipur & 5000 & 21.92 & 3.38 \\
\hline 13 & Mirzapur & 4500 & 16.73 & 3.04 \\
\hline 14 & Belabo & 4400 & 50.25 & 2.98 \\
\hline 15 & Bhuanpur & 3900 & 24.53 & 2.64 \\
\hline 16 & Kaliakair & 3800 & 28.48 & 2.57 \\
\hline 17 & Delduar & 3500 & 26.66 & 2.37 \\
\hline 18 & Palash & 3000 & 60.85 & 2.03 \\
\hline 19 & Kaliganj & 2500 & 20.06 & 1.69 \\
\hline 20 & Narsingdi & 1900 & 16.18 & 1.29 \\
\hline 21 & Rupganj & 1800 & 17.48 & 1.22 \\
\hline 22 & Nagarpur & 1800 & 8.39 & 1.22 \\
\hline 23 & Tangail & 1700 & 8.47 & 1.15 \\
\hline 24 & Savar & 1400 & 9.88 & 0.95 \\
\hline 25 & Dhamrai & 530 & 2.38 & 0.36 \\
\hline 26 & Saturia & 530 & 5.60 & 0.36 \\
\hline 27 & Bsail & 500 & 3.89 & 0.34 \\
\hline 28 & Manikganj & 450 & 2.61 & 0.30 \\
\hline 29 & Araihazar & 300 & 2.24 & 0.20 \\
\hline 30 & Keranjganj & 100 & 1.07 & 0.07 \\
\hline 31 & Narayanganj & 100 & 2.76 & 0.07 \\
\hline \multirow[t]{2}{*}{32} & Dohar & 10 & 0.16 & 0.01 \\
\hline & Dhaka region & 147820 & 22.59 & 100.00 \\
\hline
\end{tabular}

This pattern is distributed over 24 upazilas where Mirzapur upazila of Tangail district ranked in top position. This upazila has 6,000 ha area for Boro-B. Aman which is only $22.31 \%$ of upazila NCA. Nagarpur upazila of the same district ranks in third position with 5,500 ha area for this pattern, however, this upazila has allotted the biggest share $(25.63 \%)$ of its NCA.

\section{Fifth dominant cropping pattern}

Fifth dominant cropping pattern MustardBoro-B.Aman has occupied 26,600 hectares representing $4.06 \%$ share of NCA in Dhaka region (Table 13). This pattern is distributed over 21 upazilas where Shibalaya upazila of
Manikganj district ranked in top position. This upazila has 4,300 ha area Mustard-Boro-B. Aman, which is $37.07 \%$ of upazila NCA and it is $16.17 \%$ of the total patern area in the region. The second ranking upazila is Singair of Manikganj district where area coverage for this pattern is $23.41 \%$ of upazila NCA and it is $14.29 \%$ of total pattern area in the region.

\section{Crop diversity and cropping intensity}

Higher number of available crops under cultivation in an area dictates its higher diversity. Number of cropping patterns is also a gross indicator of crop diversity. A total of 164 cropping patterns were identified in the whole 
Table 10. Distribution of the second dominant Boro-F-F cropping pattern in Dhaka region, 2014-15.

\begin{tabular}{|c|c|c|c|c|}
\hline & Upazila & Area (ha) & $\%$ of upazila NCA & $\%$ of the pattern in region \\
\hline 01 & Sreenagar & 9300 & 74.82 & 8.49 \\
\hline 02 & Raipur & 8400 & 36.82 & 7.67 \\
\hline 03 & Kaliganj & 6950 & 55.76 & 6.35 \\
\hline 04 & Nawabganj & 6800 & 41.67 & 6.21 \\
\hline 05 & Savar & 6400 & 45.18 & 5.84 \\
\hline 06 & Sreepur & 5800 & 27.53 & 5.30 \\
\hline 07 & Rupganj & 5500 & 53.40 & 5.02 \\
\hline 08 & Sonargaon & 5400 & 60.61 & 4.93 \\
\hline 09 & Kaliakair & 5200 & 38.97 & 4.75 \\
\hline 10 & Narsingdi & 5100 & 43.44 & 4.66 \\
\hline 11 & Kapasia & 3700 & 18.82 & 3.38 \\
\hline 12 & Kalihati & 3600 & 17.34 & 3.29 \\
\hline 13 & Gazipur & 3500 & 18.52 & 3.20 \\
\hline 14 & Araihazar & 3100 & 23.18 & 2.83 \\
\hline 15 & Dohar & 2900 & 47.29 & 2.65 \\
\hline 16 & Lohajang & 2700 & 32.49 & 2.47 \\
\hline 17 & Tangail & 2500 & 12.45 & 2.28 \\
\hline 18 & Gazaria & 2400 & 39.09 & 2.19 \\
\hline 19 & Bandar & 2100 & 60.34 & 1.92 \\
\hline 20 & Shibalaya & 1900 & 16.38 & 1.73 \\
\hline 21 & Gopalpur & 1600 & 10.77 & 1.46 \\
\hline 22 & Daulatpur & 1450 & 10.18 & 1.32 \\
\hline 23 & Mirzapur & 1300 & 4.83 & 1.19 \\
\hline 24 & Serajdikhan & 1200 & 8.74 & 1.10 \\
\hline 25 & Bsail & 1200 & 9.35 & 1.10 \\
\hline 26 & Keraniganj & 1150 & 12.33 & 1.05 \\
\hline 27 & Shibpur & 900 & 7.36 & 0.82 \\
\hline 28 & Palash & 800 & 16.23 & 0.73 \\
\hline 29 & Bhuanpur & 800 & 5.03 & 0.73 \\
\hline 30 & Harirampur & 600 & 4.20 & 0.55 \\
\hline 31 & Munsiganj & 600 & 5.39 & 0.55 \\
\hline 32 & Ghior & 550 & 5.30 & 0.50 \\
\hline 33 & Dhamrai & 500 & 2.25 & 0.46 \\
\hline 34 & Belabo & 500 & 5.71 & 0.46 \\
\hline 35 & Dhanbari & 500 & 4.55 & 0.46 \\
\hline 36 & Ghatail & 500 & 1.69 & 0.46 \\
\hline 37 & Shakhipur & 500 & 2.28 & 0.46 \\
\hline 38 & Monohardi & 400 & 3.39 & 0.37 \\
\hline 39 & Saturia & 350 & 3.70 & 0.32 \\
\hline 40 & Narayanganj & 300 & 8.29 & 0.27 \\
\hline 41 & Manikganj & 230 & 1.34 & 0.21 \\
\hline 42 & Tungbari & 200 & 1.98 & 0.18 \\
\hline 43 & Singair & 100 & 0.62 & 0.09 \\
\hline \multirow[t]{2}{*}{44} & Madhupur & 50 & 0.20 & 0.05 \\
\hline & Dhaka region & 109530 & 16.74 & 100.00 \\
\hline
\end{tabular}


Table 11. Distribution of the third dominant Mustard-Boro-Fallow cropping pattern in Dhaka region, $2014-15$.

\begin{tabular}{|c|c|c|c|c|}
\hline & Upazila & Area (ha) & $\%$ of upazila NCA & $\%$ of the pattern in region \\
\hline 01 & Manikganj & 6100 & 35.42 & 11.89 \\
\hline 02 & Mirzapur & 5100 & 18.97 & 9.94 \\
\hline 03 & Ghior & 4300 & 41.44 & 8.38 \\
\hline 04 & Nagarpur & 4300 & 20.04 & 8.38 \\
\hline 05 & Dhamrai & 3700 & 16.65 & 7.21 \\
\hline 06 & Singair & 3350 & 20.64 & 6.53 \\
\hline 07 & Daulatpur & 3000 & 21.07 & 5.85 \\
\hline 08 & Harirampur & 2900 & 20.29 & 5.65 \\
\hline 09 & Bsail & 2800 & 21.81 & 5.46 \\
\hline 10 & Nawabganj & 2700 & 16.54 & 5.26 \\
\hline 11 & Tangail & 2600 & 12.95 & 5.07 \\
\hline 12 & Serajdikhan & 1500 & 10.92 & 2.92 \\
\hline 13 & Keraniganj & 1400 & 15.01 & 2.73 \\
\hline 14 & Kaliakair & 1400 & 10.49 & 2.73 \\
\hline 15 & Shibalaya & 800 & 6.90 & 1.56 \\
\hline 16 & Savar & 700 & 4.94 & 1.36 \\
\hline 17 & Delduar & 700 & 5.33 & 1.36 \\
\hline 18 & Bandar & 500 & 14.37 & 0.97 \\
\hline 19 & Sonargaon & 500 & 5.61 & 0.97 \\
\hline 20 & Narsingdi & 500 & 4.26 & 0.97 \\
\hline 21 & Kalihati & 450 & 2.17 & 0.88 \\
\hline 22 & Sreenagar & 350 & 2.82 & 0.68 \\
\hline 23 & Gazaria & 300 & 4.89 & 0.58 \\
\hline 24 & Araihazar & 300 & 2.24 & 0.58 \\
\hline 25 & Rupganj & 300 & 2.91 & 0.58 \\
\hline 26 & Shakhipur & 300 & 1.37 & 0.58 \\
\hline 27 & Dohar & 150 & 2.45 & 0.29 \\
\hline 28 & Lohajang & 150 & 1.81 & 0.29 \\
\hline 29 & Tungibari & 70 & 0.69 & 0.14 \\
\hline 30 & Kapasia & 50 & 0.25 & 0.10 \\
\hline \multirow[t]{2}{*}{31} & Shibpur & 30 & 0.25 & 0.06 \\
\hline & Dhaka region & 51300 & 7.84 & 100.00 \\
\hline
\end{tabular}

area of Dhaka region under this investigation. The highest number of cropping patterns was identified 35 in Tangail sadar upazila and Dhamrai upazila of Dhaka district followed by 31 in Daulatpur upazila in Manikganj district (Table 14). The lowest number of cropping patterns was identified seven in Bandar of Narayanganj district and Palash of Narsingdi district followed by eight in Sreenagar and sadar upazila of Munsiganj district. Higher number of cropping patterns is generally related to higher level of diversity indices for cropping pattern. The upazilas having lower number of cropping patterns were related to water logging. The lowest diversity index for cropping pattern was recorded 0.37 in Dhanbari of Tangail district followed by 0.47 in Shibpur of Narsingdi. In a study Shahidullah et al. (2006) also found lowest values for all the diversity and intensity parameters in salt affected and water-stagnant area of greater Noakhali. The highest value of diversity index for cropping pattern was found 0.93 in Tangail sadar upazila and that was followed by 0.90 in Bhuanpur upazila of the same district. The lowest CDI was reported 0.70 in Dhanbari of Tangail followed by 0.72 in Monohardi of Narsingdi district. The highest value of CDI was observed 0.97 in Tangail sadar upazila followed by 0.95 
Table 12. Distribution of the fourth dominant Boro-B. Aman cropping pattern in Dhaka region, 2014-15.

\begin{tabular}{|c|c|c|c|c|}
\hline & Upazila & Area (ha) & $\%$ of upazila NCA & $\%$ of the pattern in region \\
\hline 01 & Mirzapur & 6000 & 22.31 & 14.98 \\
\hline 02 & Dhamrai & 5600 & 25.20 & 13.98 \\
\hline 03 & Nagarpur & 5500 & 25.63 & 13.73 \\
\hline 04 & Kalihati & 4000 & 19.27 & 9.99 \\
\hline 05 & Delduar & 3600 & 27.42 & 8.99 \\
\hline 06 & Araihazar & 3100 & 23.18 & 7.74 \\
\hline 07 & Bsail & 2500 & 19.47 & 6.24 \\
\hline 08 & Tangail & 1600 & 7.97 & 4.00 \\
\hline 09 & Ghatail & 1500 & 5.08 & 3.75 \\
\hline 10 & Saturia & 1400 & 14.80 & 3.50 \\
\hline 11 & Bhuanpur & 1150 & 7.23 & 2.87 \\
\hline 12 & Kapasia & 700 & 3.56 & 1.75 \\
\hline 13 & Manikganj & 500 & 2.90 & 1.25 \\
\hline 14 & Raipur & 500 & 2.19 & 1.25 \\
\hline 15 & Shakhipur & 500 & 2.28 & 1.25 \\
\hline 16 & Keraniganj & 470 & 5.04 & 1.17 \\
\hline 17 & Serajdikhan & 400 & 2.91 & 1.00 \\
\hline 18 & Sonargaon & 400 & 4.49 & 1.00 \\
\hline 19 & Nawabganj & 200 & 1.23 & 0.50 \\
\hline 20 & Kaliakair & 100 & 0.75 & 0.25 \\
\hline 21 & Bandar & 100 & 2.87 & 0.25 \\
\hline 22 & Rupganj & 100 & 0.97 & 0.25 \\
\hline 23 & Kaliganj & 80 & 0.64 & 0.20 \\
\hline \multirow[t]{2}{*}{24} & Gopalpur & 50 & 0.34 & 0.12 \\
\hline & Dhaka region & 40050 & 6.12 & 100.00 \\
\hline
\end{tabular}

Table 13. Distribution of the fifth dominant Mustard-Boro-B. Aman cropping pattern in Dhaka region, $2014-15$.

\begin{tabular}{|c|c|c|c|c|}
\hline & Upazila & Area (ha) & $\%$ of upazila NCA & $\%$ of the pattern in region \\
\hline 01 & Shibalaya & 4300 & 37.07 & 16.17 \\
\hline 02 & Singair & 3800 & 23.41 & 14.29 \\
\hline 03 & Bsail & 2900 & 22.59 & 10.9 \\
\hline 04 & Nagarpur & 2400 & 11.18 & 9.02 \\
\hline 05 & Daulatpur & 1900 & 13.34 & 7.14 \\
\hline 06 & Mirzapur & 1900 & 7.07 & 7.14 \\
\hline 07 & Ghior & 1300 & 12.53 & 4.89 \\
\hline 08 & Manikganj & 1300 & 7.55 & 4.89 \\
\hline 09 & Narsingdi & 1000 & 8.52 & 3.76 \\
\hline 10 & Nawabganj & 800 & 4.90 & 3.01 \\
\hline 11 & Delduar & 800 & 6.09 & 3.01 \\
\hline 12 & Tangail & 750 & 3.74 & 2.82 \\
\hline 13 & Harirampur & 700 & 4.90 & 2.63 \\
\hline 14 & Araihazar & 700 & 5.23 & 2.63 \\
\hline 15 & Kalihati & 600 & 2.89 & 2.26 \\
\hline 16 & Gopalpur & 500 & 3.36 & 1.88 \\
\hline 17 & Keraniganj & 400 & 4.29 & 1.50 \\
\hline 18 & Serajdikhan & 300 & 2.18 & 1.13 \\
\hline 19 & Dohar & 100 & 1.63 & 0.38 \\
\hline 20 & Kaliakair & 100 & 0.75 & 0.38 \\
\hline \multirow[t]{2}{*}{21} & Savar & 50 & 0.35 & 0.19 \\
\hline & Dhaka region & 26600 & 4.06 & 100.00 \\
\hline
\end{tabular}


Table 14. Crop diversity and cropping intensity in Dhaka region, 2014-15.

\begin{tabular}{|c|c|c|c|c|c|c|}
\hline & Upazila & $\begin{array}{c}\text { No. of identified } \\
\text { pattern }\end{array}$ & No. of crop & $\begin{array}{l}\text { Diversity index for } \\
\text { cropping pattern }\end{array}$ & $\begin{array}{l}\text { Crop diversity } \\
\text { index (CDI) }\end{array}$ & C.I. (\%) \\
\hline 01 & Dhamrai & 35 & 20 & 0.88 & 0.95 & 224 \\
\hline 02 & Dohar & 30 & 20 & 0.76 & 0.84 & 161 \\
\hline 03 & Keraniganj & 22 & 21 & 0.89 & 0.94 & 213 \\
\hline 04 & Nawabganj & 18 & 19 & 0.77 & 0.90 & 175 \\
\hline 05 & Savar & 14 & 13 & 0.72 & 0.91 & 177 \\
\hline 06 & Gazipur sadar & 19 & 12 & 0.84 & 0.91 & 180 \\
\hline 07 & Kapasia & 14 & 12 & 0.78 & 0.84 & 158 \\
\hline 08 & Kaliakair & 17 & 13 & 0.75 & 0.87 & 167 \\
\hline 09 & Kaliganj & 15 & 16 & 0.64 & 0.83 & 150 \\
\hline 10 & Sreepur & 18 & 11 & 0.77 & 0.85 & 148 \\
\hline 11 & Daulatpur & 31 & 23 & 0.90 & 0.94 & 193 \\
\hline 12 & Ghior & 21 & 16 & 0.80 & 0.89 & 201 \\
\hline 13 & Harirampur & 21 & 21 & 0.90 & 0.94 & 178 \\
\hline 14 & Manikganj sadar & 29 & 21 & 0.85 & 0.93 & 219 \\
\hline 15 & Saturia & 16 & 14 & 0.84 & 0.93 & 239 \\
\hline 16 & Shibalaya & 10 & 10 & 0.79 & 0.89 & 222 \\
\hline 17 & Singair & 25 & 16 & 0.87 & 0.94 & 233 \\
\hline 18 & Gazaria & 12 & 11 & 0.79 & 0.89 & 153 \\
\hline 19 & Lohaganj & 15 & 18 & 0.79 & 0.90 & 162 \\
\hline 20 & Munsiganj sadar & 18 & 17 & 0.66 & 0.82 & 197 \\
\hline 21 & Sreenagar & 8 & 9 & 0.66 & 0.82 & 124 \\
\hline 22 & Serajdikhan & 17 & 12 & 0.89 & 0.95 & 212 \\
\hline 23 & Tungibari & 14 & 14 & 0.73 & 0.86 & 201 \\
\hline 24 & Araihazar & 25 & 17 & 0.83 & 0.92 & 186 \\
\hline 25 & Bandar & 7 & 7 & 0.60 & 0.85 & 146 \\
\hline 26 & Nrayanganj sadar & 8 & 8 & 0.76 & 0.88 & 206 \\
\hline 27 & Rupganj & 20 & 17 & 0.67 & 0.80 & 136 \\
\hline 28 & Sonargaon & 22 & 18 & 0.61 & 0.75 & 127 \\
\hline 29 & Belabo & 19 & 17 & 0.61 & 0.75 & 226 \\
\hline 30 & Monohardi & 11 & 11 & 0.49 & 0.72 & 195 \\
\hline 31 & Narsingdi sadar & 14 & 14 & 0.76 & 0.88 & 158 \\
\hline 32 & Palash & 7 & 6 & 0.60 & 0.77 & 187 \\
\hline 33 & Raipur & 20 & 17 & 0.79 & 0.89 & 156 \\
\hline 34 & Shibpur & 19 & 17 & 0.47 & 0.73 & 201 \\
\hline 35 & Basail & 18 & 15 & 0.85 & 0.93 & 225 \\
\hline 36 & Bhuanpur & 25 & 24 & 0.90 & 0.95 & 208 \\
\hline 37 & Delduar & 22 & 18 & 0.84 & 0.93 & 220 \\
\hline 38 & Dhanbari & 12 & 11 & 0.37 & 0.70 & 207 \\
\hline 39 & Ghatail & 14 & 13 & 0.62 & 0.79 & 189 \\
\hline 40 & Gopalpur & 24 & 18 & 0.57 & 0.81 & 213 \\
\hline 41 & Kalihati & 24 & 16 & 0.82 & 0.92 & 209 \\
\hline 42 & Madhupur & 16 & 13 & 0.79 & 0.83 & 157 \\
\hline 43 & Mirzapur & 26 & 21 & 0.87 & 0.94 & 205 \\
\hline 44 & Nagarpur & 19 & 15 & 0.85 & 0.94 & 227 \\
\hline 45 & Shakhipur & 13 & 13 & 0.58 & 0.80 & 212 \\
\hline \multirow[t]{2}{*}{46} & Tangail sadar & 35 & 26 & 0.93 & 0.97 & 208 \\
\hline & Dhaka region & 164 & 36 & 0.90 & 0.94 & 191 \\
\hline
\end{tabular}

138 Parvin et al 
in Dhanbari and Bhuanpur of Tangail and Serajdikhan upazila of Munsiganj district.

The range of cropping intensity values was recorded $124-239 \%$. The maximum value was for Saturia upazila of Manikganj district and minimum for Sreenagar upazila of Munsiganj district. As a whole the CDI of Dhaka region was calculated 0.94 and the average cropping intensity at regional level was $191 \%$. In a simultaneous study, the investigators identified 316 cropping patterns for whole Bangladesh; where the CDI value was 0.95 at national level and the national average of cropping intensity was 200\% (Nasim et al., 2017). Diversification of crops helps risk reduction as diversification allows a producer to balance low price in one or two crops with reasonable prices in the other. (Blade and Slinkard, 2002). The farmers of Kerala diversified their cropping pattern to minimize risk from due to crop failures and price fluctuations (Mahesh, 1999).

\section{CONCLUSION}

In total, the highest cropping intensity was observed in Saturia upazila and lowest was in Sreenagar upazila under Dhaka region. The cropping intensity of the Dhaka region was little bit lower than the national average. BoroFallow-T. Aman, Single Boro, Mustard-BoroFallow, Boro-B. Aman were the dominant cropping patterns in the region. Exclusive rice area is about three folds of exclusive non-rice area. In Dhaka region, crop diversity is much wider than that of other regions. However, pulse crops and oil-seed crops are not sufficient in the crop distributions and cropping sequences. Based on the findings of the study, the following recommendations were made.

- Initiative should to be taken to increase productivity of exclusive rice based cropping patterns with high yielding varieties of rice along with recommended crop management packages.

- The upazilas having unique or exceptional cropping patterns with large area coverage might be studied in-depth to extrapolate to similar environments.
- A portion of single T. Aman area could be bought under double rice area with inclusion of Aus.

- Emphasis should be given so that a portion of double-rice area could be brought under Mustard-Boro-T. Aman cropping system or other three cropping systems.

- Area under deepwater rice might be intensified by relay cropping.

\section{REFERENCES}

BBS (Bangladesh Bureau of Statistics). 2014. Statistical Yearbook of Bangladesh. Statistics Division, Ministry of Planning, Government of the People's Republic of Bangladesh.

Blade, S F and A E Slinkard 2002. New Crop Development: The Canadian Experience. In: Trends in New Crops and New Uses. J Janick and A Whipkey (Editors). ASHS Press, Alexandria.

Chand, R. 1996. Diversification through high value crops in western Himalayan region: evidence from Himachal Pradesh. Indian J. Agric. Econ. 51(4): 652-663.

Das, Anup, G I Ramkrushna, GS Yadav, J Layek, C Debnath, B U Choudhury, K P Mohaptara, S V Ngachan and S Das. 2015. Capturing traditional practices of rice based farming systems and identifying interventions for resource conservation and food security in Tripura, India. Applied Ecology and Environmental Sciences. 3(4): 100-107.

FAO. 1988. Land Resources Appraisal of Bangladesh for Agricultural Development- Report 2: Agroecological regions of Bangladesh. Food and Agriculture Organization of the United Nations, Rome, Italy. 570p.

Jackson, B R, A Yantasast, C Prechachat, M A Chowdhury and S M H Zaman. 1972. Breeding rice for deep-water areas. International Rice Research Institute, Rice Breeding, Los Baños, Philippines. 517-528.

Kshirsagar, K G, S Pandey and M R Bellon. 1997. Farmers' perception, varietal characteristics and technology adoption: the case of rainfed village in eastern India. Discussion paper. Social Sciences Division, International Rice Research Institute. Los Baňos, Laguna, Philippines. 5(97).

Mandal, R and M P Bezbaruah. 2013. Diversification of cropping pattern: its determinants and role in flood affected agriculture of Assam Plains. Indian J. Agric. Econ. 68(2): 169-181.

Muttaleb, M A, S M Shahidullah, M Nasim and A Saha. 2017. Cropping systems and land use in Sylhet region. Bangladesh Rice J. 21(2): 273-288. 
Nasim, M, S M Shahidullah, A Saha, M A Muttaleb, T L Aditya, M A Ali and M S Kabir. 2017. Distribution of Crops and Cropping Patterns in Bangladesh. Bangladesh Rice J. 21(2): 1-55.

Pingali, P I and M W Rosegrant. 1995. Agricultural commercialization and diversification: process and policies, Food Policy. 20(3): 171-186.

Salam, M U, S M A Hossain, J K Biswas and A J Mridha. 2014. Managing the unmanageable: rice variety technology for future challenging food security in Bangladesh. Extended abstract in the 'Agronomic visions in challenging future', the proceedings of the $13^{\text {th }}$ conference of the Bangladesh Society of Agronomy, 20 September 2014, Bangladesh Rice Research Institute (BRRI), Gazipur, Bangladesh.

Shahidullah, S M, M S A Talukder, M S Kabir, A H Khan and N E Elahi. 2006. Cropping patterns in the South East Coastal Region of Bangladesh. J. Agric. Rural Dev. 4(1\&2): 53-60.

Shahidullah, S M, M Nasim, M K Quais and A Saha. 2017. Diversity of Cropping Systems in Chittagong Region. Bangladesh Rice J. 21(2): 109-122.

Shriar, A J. 2000. Agricultural intensity and its measurement in frontier regions. Agroforestry Systems. 49(3): 301-318.

Appendix 1. List of cropping patterns in Dhaka region, 2014-15.

\begin{tabular}{|c|c|c|c|c|c|}
\hline & Cropping pattern & Area (ha) & & Cropping pattern & Area (ha) \\
\hline 001 & Boro-Fallow-T. Aman & 147820 & 061 & Maize-Sesbania-Fallow & 1000 \\
\hline 002 & Boro-Fallow-Fallow & 109530 & 062 & Grasspea-Sesame-Fallow & 920 \\
\hline 003 & Mustard-Boro-Fallow & 51300 & 063 & Blackgram-Aus-T. Aman & 850 \\
\hline 004 & Boro-B.Aman & 40050 & 064 & Chilli-B.Aman & 820 \\
\hline 005 & Mustard-Boro-B.Aman & 26600 & 065 & Vegetab-Boro-T. Aman & 820 \\
\hline 006 & Vegetab-Vegetab-Vegetab & 26050 & 066 & Mustard-Sesame+B.Aman & 800 \\
\hline 007 & Mustard-Boro-T. Aman & 22400 & 067 & Onion-Vegtab-Vegetab & 800 \\
\hline 008 & Potato-B.Aman & 19960 & 068 & Vegetab-Fallow-Blackgram & 790 \\
\hline 009 & Potato-Sesbania & 10220 & 069 & Boro-Aus-Fallow & 780 \\
\hline 010 & Fallow-Fallow-T. Aman & 9650 & 070 & Fallow-Vegetab-T. Aman & 720 \\
\hline 011 & Vegetab-Vegetab-Fallow & 8750 & 071 & Cotton-Aus-Fallow & 700 \\
\hline 012 & Vegetab-Fallow-Fallow & 6980 & 072 & Mustard-Boro-Sesbania & 700 \\
\hline 013 & Onion-B.Aman & 5230 & 073 & Maize-Sesame-Fallow & 690 \\
\hline 014 & Boro-Jute-T. Aman & 4780 & 074 & Wheat-B.Aman & 690 \\
\hline 015 & Boro-Sesbania-Fallow & 4410 & 075 & Vegetab-Aus-T. Aman & 680 \\
\hline 016 & Potato-Jute-Fallow & 4360 & 076 & Blackgram-Jute-Fallow & 660 \\
\hline 017 & Potato-Boro-Fallow & 4050 & 077 & Garlic-B.Aman & 640 \\
\hline 018 & Boro-Fallow-Blackgram & 3955 & 078 & Potato-Maize-Fallow & 610 \\
\hline 019 & Groundnut-Fallow-Fallow & 3620 & 079 & Sesame+B.Aman-Blackgram & 600 \\
\hline 020 & Fallow-Fallow-Blackgram & 3415 & 080 & Coriander-Vegetab-Fallow & 580 \\
\hline 021 & Potato-Jute-T. Aman & 3360 & 081 & Chilli-Vegetab-Fallow & 570 \\
\hline 022 & Maize-Maize-Fallow & 3280 & 082 & Mustard-Jute-Fallow & 560 \\
\hline 023 & Wheat-Jute-T. Aman & 3245 & 083 & Coriander-B.Aman & 550 \\
\hline 024 & Blackgram-B.Aman & 3090 & 084 & Garlic-Jute-Fallow & 530 \\
\hline 025 & Potato-Boro-T. Aman & 3090 & 085 & Onion-Jute-T. Aman & 530 \\
\hline 026 & Grasspea-B.Aman & 2970 & 086 & Tobacco-Boro-T. Aman & 450 \\
\hline 027 & Maize-Jute-Fallow & 2790 & 087 & Potato-Vegetab-T. Aman & 440 \\
\hline 028 & Vegetab-Boro-Fallow & 2590 & 088 & Grasspea-Jute-Fallow & 420 \\
\hline 029 & Boro-Sesbania-T. Aman & 2440 & 089 & Groundnut-B.Aman & 420 \\
\hline 030 & Boro-Vegetab(Float/Norm) & 2360 & 090 & Chilli-Fallow-T. Aman & 400 \\
\hline 031 & Maize-Fallow-Fallow & 2265 & 091 & Potato-Fallow-T. Aman & 400 \\
\hline 032 & Vegetab-Jute-Fallow & 2170 & 092 & Potato-Maize-T. Aman & 400 \\
\hline 033 & Maize-B.Aman & 1920 & 093 & Tobacco-Maize-T. Aman & 400 \\
\hline 034 & Sesame-Fallow-Blackgram & 1850 & 094 & Coriander-Fallow-Fallow & 390 \\
\hline 035 & Fallow-Jute-T. Aman & 1770 & 095 & Vegetab-Fallow-T. Aman & 360 \\
\hline
\end{tabular}

140 Parvin et al 
Appendix 1. Continued.

\begin{tabular}{|c|c|c|c|c|c|}
\hline & Cropping pattern & Area (ha) & & Cropping pattern & Area (ha) \\
\hline 036 & Maize-Vegetab-Fallow & 1700 & 096 & Lentil-Sesame-Fallow & 355 \\
\hline 037 & Vegetab-B.Aman & 1690 & 097 & Blackgram-Jute-T. Aman & 350 \\
\hline 038 & Vegetab-Vegetab-T. Aman & 1660 & 098 & Pea-Vegetab-Fallow & 350 \\
\hline 039 & Wheat-Jute-Fallow & 1560 & 099 & Coriander-Jute-Fallow & 330 \\
\hline 040 & Chilli-Fallow-Fallow & 1490 & 100 & Lentil-B.Aman & 330 \\
\hline 041 & S.Potato-Fallow-Fallow & 1430 & 101 & Potato-Chilli-Fallow & 330 \\
\hline 042 & Maize-Fallow-T. Aman & 1390 & 102 & Lentil-Vegetab-Vegetab & 320 \\
\hline 043 & Potato-Sesame-Fallow & 1390 & 103 & Grasspea-B.Aus+B.Aman & 300 \\
\hline 044 & Grasspea-Sesbania-Fallow & 1350 & 104 & Potato+Maize-B.Aman & 300 \\
\hline 045 & Onion-Jute-Fallow & 1350 & 105 & Boro-Jute-Fallow & 280 \\
\hline 046 & Mustard-B.Aman & 1340 & 106 & Mustard-Boro-Jute-T. Aman & 240 \\
\hline 047 & S.Potato-Jute-Fallow & 1230 & 107 & Mustard-Jute-T. Aman & 220 \\
\hline 048 & Boro-Aus-T. Aman & 1215 & 108 & Fallow-Sesame+B.Aman & 200 \\
\hline 049 & Boro-Vegetab-T. Aman & 1200 & 109 & Potato-Sesame-Aus & 200 \\
\hline 050 & Vegetab-Maize-Fallow & 1170 & 110 & Pea-B.Aman & 170 \\
\hline 051 & Grasspea-Jute-T. Aman & 1150 & 111 & Potato-Groundnut & 170 \\
\hline 052 & Lentil-Jute-T. Aman & 1120 & 112 & Chilli-Vegetab-T. Aman & 150 \\
\hline 053 & Vegetab-Jute-T. Aman & 1120 & 113 & Fallow-Aus-T. Aman & 150 \\
\hline 054 & Mustard-Boro-Jute & 1100 & 114 & Garlic-Fallow-Fallow & 150 \\
\hline 055 & Wheat-Maize-T. Aman & 1100 & 115 & Maize-Fallow-Blackgram & 150 \\
\hline 056 & Grasspea-Fallow-Fallow & 1060 & 116 & Garlic-Vegetab-Vegetab & 135 \\
\hline 057 & Chilli-Jute-Fallow & 1050 & 117 & Garlic-Jute-T. Aman & 110 \\
\hline 058 & Maize-Jute-T. Aman & 1050 & 118 & Potato-Aus-Fallow & 110 \\
\hline 059 & Lentil-Jute-Fallow & 1040 & 119 & Wheat-Chilli-Fallow & 110 \\
\hline 060 & Maize-Maize-T. Aman & 1000 & $120-164$ & Other 45 patterns (Table 8 ) & 3045 \\
\hline
\end{tabular}


